\title{
ORTODOKSI TAFSIR SUNNI: FORMASI, GENERALISASI DAN INVESTIGASI TEORI
}

\author{
Ahmad Ali Fikri \\ UIN Syarif Hidayatullah Jakarta, Indonesia \\ E-mail: fikrieahmed@gmail.com
}

\begin{abstract}
The difference and plurality of interpretations of the Qur'an is a fact that cannot be denied. Nevertheless, in an interpreting community always shows a uniqueness that draws a line of difference from other interpreting communities. This article discusses the orthodoxy of interpretations that developed widely in the Sunni tradition by adopting and modifying the orthodoxy concept developed by David C. Martin, Abbas Barzegar and Norman Calder, then to be investigated through al-Ittijahat al-Munharifah fi Tafsir al-Qur'an: Dawa fi'uha wa Dafuha by Muhammad Husein al-Dzahabi. This paper shows that the orthodoxy of Sunni interpretation is built on three fundamental structures; textual orientation, recognition of the authority of previous generations, and theological identification of Sunni groups.
\end{abstract}

Keywords: Interpretation of the Qur'an; Orthodoxy; Sunni Interpretation

Abstrak. Perbedaan dan pluralitas penafsiran terhadap al-Qur'an merupakan sebuah fakta yang tidak bisa dipungkiri. Kendati demikian, dalam sebuah komunitas penafsiran selalu menunjukkan keunikan yang menarik garis perbedaan dari komunitas penafsiran yang lain. Artikel ini membahas tentang ortodoksi tafsir yang berkembang secara luas dalam tradisi Sunni dengan mengadopsi dan memodifikasi konsep ortodoksi yang dikembangkan oleh David C. Martin, Abbas Barzegar dan Norman Calder untuk kemudian diuji melalui buku al-Ittijahat al-Munharifah fi Tafsir al-Qur'an: Dawafi'uha wa Dafuha karya Muhammad Husein al-Dzahabi. Tulisan ini menunjukkan bahwa ortodoksi tafsir Sunni dibangun di atas tiga struktur mendasar, orientasi tekstual, pengakuan terhadap otoritas generasi terdahulu, serta identifikasi teologis kelompok Sunni.

Kata kunci: Tafsir al-Qur'an; Ortodoksi; Tafsir Sunni

Permalink/DOI: https://doi.org/10.15408/mimbar.v36i1.12960 


\section{Pendahuluan}

Penafsiran al-Qur'an, pertama-tama, pada satu sisi harus dipahami sebagai upaya manusia (human endevaour) dalam berinteraksi dan memahami teks al-Qur'an dan harus dibedakan dengan wahyu (revelation) pada sisi yang lain. Implikasinya, setiap penafsiran yang dilakukan orang-orang tertentu tidak bisa dianggap sebagai sesuatu yang suci (sacred) karena ia selalu merupakan sebuah proses yang dibatasi oleh konteks dan budayanya masing-masing (Saeed, 2006:4). Keterikatannya pada konteks itu, pada tahap selanjutnya, membuat sebuah produk penafsiran selalu memiliki latar belakang, motif, perspektif, dan orientasi-orientasi yang berbeda dari produk tafsir lainnya. Hal ini sesuai dengan apa yang pernah dikemukakan oleh David Tietge bahwa sebuah makna (tafsir) selalu merupakan rekonstruksi dari tiga hal; intensi pengarang, otoritas teks, dan sekaligus subjektivitas pembaca (reader)—dalam konteks ini adalah mufassir (interpreter) (Tietge, 2004:973). Tidak heran jika perbedaan dalam penafsiran menjadi realitas yang tidak bisa dipungkiri. Bahkan sebuah karya tafsir yang diasumsikan bertautan secara intens dengan karya tafsir sebelumnya tetap saja di dalamnya terdapat perbedaan meski dalam bentuknya yang sangat subtil (Al-Khalidi, 2008:474-475). Berdasarkan perspektif semacam ini, maka sebuah upaya penafsiran akan selalu dipandang sebagai proses yang di dalamnya mengakomodasi perbedaan sekaligus pluralitas pendapat antara satu mufasir dengan yang lainnya. Bahkan dalam kasus penafsiran yang dilakukan dengan teknik dan metode yang sama sekalipun.

Persoalan perbedaan dan pluralitas penafsiran tersebut oleh sebagian peneliti diasumsikan sebagai konsekuensi dari dua hal penting. Pertama, watak al-Qur'an sendiri yang dalam banyak kasus memang membuka ruang terhadap munculnya perbedaan dalam penafsirannya (Calder, 1993:121124). Kedua, faktor non-tektualitas al-Qur'an yang berhubungan dengan aspek-aspek yang melingkupi para mufasir itu sendiri, seperti aspek teologi, sosial, budaya, psikologi, dan intelektual.

Kendati demikian, fakta perbedaan dan pluralitas penafsiran ini umumnya bertentangan dengan pandangan normatif. Bagi kelompok ini, kebenaran al-Qur'an itu tunggal sekaligus ahistoris. Dengan kata lain, di tengah ragam penafsiran dalam konteks ayat-ayat tertentu dalam al-Qur'an akan selalu ada satu penafsiran yang benar; jika yang terjadi adalah perbedaan-perbedaan yang bisa diakomodasi dan dikompromikan maka pada dasaranya ia sekedar perbedaan aksentuasi saja. Tetapi jika perbedaan penafsiran itu sangat kuat dan tidak bisa didamaikan, maka salah satu dari ragam penafsiran tersebut ada yang benar sementara yang lain salah. Konsekuensinya, pada tahap berikutnya, perbedaan dalam penafsiran itu akan lebih kompleks dan akan ditarik pada wilayah benar-salah, absah-tidak absah, atau ortodoksi dan heterodoksi (Utsaimin : 21-138).

Persoalannya kemudian, mungkinkah kriteria ortodoksi tafsir itu didefinisikan dan dideterminasi? Atas dasar apa dan mengapa sebuah teori penafsiran bisa dikategorikan sebagai ortodoks atau heterodoks? Dalam banyak persoalan yang menjadi ajang perdebatan di kalangan mufasir, pendapat manakah yang dianggap paling otoritatif dalam merepresentasikan sebuah ortodoksi? Mungkinkah kita membatasi sesuatu yang banyak pihak, dengan pandangan dan pendapatnya masingmasing, ingin dianggap sebagai bagian dari ortodoksi tersebut?

Berhadapan dengan problem-problem di atas, penulis meyakini bahwa adalah mungkin untuk membatasi dan mendefinisikan struktur dasar ortodoksi tafsir seperti yang dilakukan oleh David C. Martin dan Abbas Barzegar dalam artikelnya "Formations of Orthodoxy: Authority, Power, and Networks in Muslim Societies” yang menyatakan bahwa ortodoksi terbentuk di atas tiga hal; otoritas, 
kekuatan, dan jaringan-jaringan dalam sebuah komunitas (Martin \& Barzegar, 2010:179-202). Hanya saja, harus diupayakan bahwa pembatasan itu bersifat general dan longgar. "general" dalam arti bahwa ia dituntut untuk mencari prinsip-prinsip yang relatif permanen dan tidak berubah dari masa ke masa. "longgar" dalam arti bahwa ia dikonstruksi di atas asumsi yang rigid bahwa ortodoksi dibangun sekali dan untuk selamanya, namun tidak dalam rangka menengahi atau mereduksi perdebatan-perdebatan yang mengemuka dalam kajian tafsir sepanjang beberapa abad lamanya. Selain itu, pembatasan itu direkonstruksi dengan sifatnya yang sosiologis dari pada normatif. Dengan demikian, ia dihadirkan untuk sekedar menjawab pertanyaan mengapa sebuah teori atau pandangan dalam tafsir diterima oleh suatu komunitas mufasir sementara pandangan lain ditolak.

Berdasarkan konteks di atas serta menyadari luasnya pembahasan ini, maka tulisan ini akan memusatkan perhatiaannya kepada dua hal saja. Pertama, melacak kriteria-kriteria atau struktur dasar dalam ortodoksi tafsir Sunni. Kedua, melakukan generalisasi dan investigasi atasnya melalui analisa terhadap kitab al-Ittijahat al-Munharifah fi Tafsir al-Quran al-'Azim: Dawafi'uha wa Dafuha karya Muhammad Husein al-Zahabi.

Harus dikemukakan disini bahwa kajian tentang ortodoksi dan heterodoksi, terutama dalam bidang teologi dan keagamaan, sudah banyak dilakukan. Misalnya artikel yang ditulis oleh Ulya yang berjudul "Ortodoksi dan Heterodoksi Wacana Keagamaan dalam Islam". Sebagaimana tampak dari judulnya, artikel ini memfokuskan pembahasannya pada persoalan kemunculan dan perkembangan klaim-klaim ortodoksi dan heterodoksi dalam wacana keagamaan di dunia Islam. Artikel serupa juga bisa dilihat dalam tulisan Richard C. Martin dan Abbas Barzegar yang berjudul "Formations of Orthodoxy: Authority, Power, and Networks in Muslim Societies" dan tulisan MacEoin yang berjudul "Orthodoxy and Heterodhoxy in Nineteenth-Century Shi' ism: The Case of Syaykhism and Babism". Artikel-artikel tersebut, tentu saja, berbeda dengan fokus kajian penulis dalam artikel ini yang pada dasarnya mencoba merekonstruksi ortodoksi tafsir dalam tradisi Sunni. Kendati demikian, artikelartikel tersebut memiliki signifikansi dengan tulisan ini karena darinya, penelitian ini meminjam dan memodifikasi beberapa konsep penting terkait struktur dasar ortodoksi dalam sebuah komunitas sebagaimana akan diuraikan pada bagian mendatang.

Adapun tulisan yang mencoba mengkaji secara spesifik tentang ortodoksi dalam diskursus tafsir adalah "Ortodoksi dan Heterodoksi Tafsir" karya Dadang Darmawan. Tulisan ini memfokuskan pada persoalan karakter dari sebuah ortodoksi tafsir yang berpijak pada perdebatan-perdebatan dalam teologi Islam. Namun artikel ini tidak menjelaskan secara sistematis tentang kriteria-kriteria dasar dalam ortodoksi tafsir terutama dalam tradisi Sunni-yang merupakan fokus utama dari kajian yang hendak penulis lakukan.

Melalui survei terhadap literatur-literatur tersebut, dapat dikemukakan bahwa penelitian ini mencoba mengisi "ruang kosong" dalam kajian tafsir guna melengkapi penelitian-penelitian yang sudah ada sebelumnya.

\section{Ortodoksi Tafsir Sunni: Upaya Melacak Kriteria dan Struktur Dasar}

Istilah ortodoksi sendiri berasal dari bahasa Yunani dan merupakan konstruksi dari dua kata: orth 'benar' dan doxa 'ajaran, pendapat'. Ia kemudian dimaknai sebagai "kepatuhan terhadap doktrin yang telah mapan, terutama dalam agama tertentu”. Sebagai sebuah terma, ia biasanya dilawankan 
dengan heterodoksi, sebagai "sebuah sikap yang berlawanan atau berbeda dengan ajaran standar yang telah diakui atau doktrin agama yang telah mapan” (Mc. Donough, 1993:124-129). Melalui definisi ini, kemudian dalam konteks ini ortodoksi dipahami sebagai sebuah kerangka yang membedakan antara "yang benar/absah" dan "yang salah/tidak absah".

Namun demikian, sering dinyatakan bahwa ortodoksi adalah sesuatu yang asing dalam konteks Islam karena tidak ada dalam Islam sebuah institusi, seperti dewan sinode atau lembaga gereja, yang memiliki otoritas untuk menentukan kriteria ortodoksi (Watt, 1973:268). Sheilla Mc. Donough menyatakan bahwa terma ortodoksi dan heterodoksi ini berasal dari tradisi Kristen, namun esensinya, sebagai konsep yang membatasi antara sesuatu yang sah dan tidak sah dalam doktrin keagamaan, ia pun ditengarai juga ada dalam tradisi agama-agama lainnya (Mc. Donough, 1993:124-129). Dalam kajian tafsir, kita juga dengan cukup aman menggunakan konsep ortodoksi melalui pertimbangan berikut.

Pertama, ortodoksi sebagai sebuah konsep dapat ditemukan dalam karya-karya para pemikir muslim awal, terutama dalam disiplin teologi dan heresiografi (Saleh, 2004:77-78). Dalam konteks tulisan ini, ortodoksi dipahami dalam kerangka pembedaan antara "yang salah" dan "yang benar". Dalam kajian tafsir, konsep tentang ortodoksi juga ada. Hal itu bisa dibuktikan banyaknya pembahasan tentang kriteria-kriteria dan contoh-contoh penafsiran yang menyimpang dalam literatur-literatur tafsir dan 'ulum al-Qur'an.

Kedua, fakta bahwa dalam setiap disiplin keilmuan selalu berlangsung proses pemapanan dan standarisasi. Dan itu juga berlaku dalam disiplin keilmuan tafsir. Dengan kata lain, prinsip-prinsip (qawaid), metode-metode, maupun terminologi-terminologi tafsir dan 'ulum al-Qur'an telah mengalami proses pemapanan yang berlangsung sekian lama; yang mapan dan standar itu kemudian menjadi arus-utama dan dianut oleh mayoritas mufasir, sementara yang berlawanan cenderung dianggap sebagai bentuk penyimpangan dari ortodoksi. Dalam penelitian ini, penyimpangan tersebut selanjutnya akan diistilahkan dengan deviasi (inhiraf).

Adapun istilah "Sunni", penelitian ini memilih untuk mendefinisikannya dari luar (outside), yaitu sebagai sebuah komunitas yang berada di luar kelompok-kelompok seperti Shi'ah, Mu’tazilah, dan Khawarij. Konsekuensinya, kategori Sunni dalam penelitian ini digunakan dengan sedikit mengabaikan varian-varian (teologi) yang terdapat dalam kelompok Sunni sendiri. Selain itu, kategori Sunni juga dianggap sebagai sesuatu yang taken for granted, yang telah ada dengan sendirinya. Karena itu, penelitian ini juga akan mengabaikan persoalan-persoalan historis yang melingkupinya, seperti tentang kapan dan dimana Sunni dan ortodoksi tafsirnya terbentuk.

Kajian tentang ortodoksi sendiri kerap dihubungkan dengan dinamika sosial, politik, dan budaya pada masa tertentu. Dengan kata lain, sebuah teori, pendekatan, atau asumsi pada suatu masa yang dianggap menjadi bagian dari ortodoksi bisa jadi pada pada masa setelahnya menjadi bagian darinya; begitu pula sebaliknya. Karena itu, sebagian atau kebanyakan peneliti, terutama pada akhirakhir ini, berpendapat bahwa ortodoksi adalah sebuah sistem nilai yang tidak statis dan abadi, justru ia merupakan fakta yang dinamis dan berkembang (evolving) (Martin \& Barzegar, 2010:179-202).

Menurut Arkoen ortodoksi Islam bermula dari munculnya perdebatan teologis selepas terbunuhnya Uthman ibn 'Affan. Peristiwa yang kemudian disusul oleh berdirinya dinasti Umayyah itu melahirkan sebuah proses dimana, 
“modal simbolik yang diemban oleh al-Qur'an digunakan untuk mengkonstruksi dan membentuk Islam yang resmi dan ortodoks; resmi karena ia lahir dari pilihan-pilihan politik negara yang mencoba mengeliminasi secara fisik para lawan yang melakukan interpretasi dan penggunaan simbolik itu secara berbeda (terutama kelompok Syi'ah dan Khawarij); ortodoks karena para ulama yang diberi kuasa secara resmi oleh otoritas-otoritas politik meyakini bahwa adalah mungkin untuk melakukan pembacaan yang benar terhadap Kalam Tuhan serta memiliki pengetahuan menyeluruh terhadap Sunnah Nabi...." (Arkoen, 1994:22).

Kutipan di atas menjelaskan dengan baik bahwa bagi Arkoen negara dan otoritas-otoritas politik merupakan faktor yang sangat menentukan bagi terbentuknya ortodoksi. Bahkan lebih jauh Arkoen menyatakan bahwa otodoksi, baik dalam dunia Sunni maupun Syi'ah, tidak lebih dari agama resmi (the official relegion) yang terbentuk melalui kolaborasi antara mayoritas ulama dan negara (Gunther, 2004:138-139).

Richard D. Martin dan Abbas Barzegar berpendapat bahwa ortodoksi Islam dibangun atas dasar tiga formasi; otoritas (authority), kekuatan (power), dan jaringan-jaringan dalam masyarakat Muslim (networks in muslim societies). Melalui tiga formasi ini, Martin kemudian menentang anggapaan umum bahwa gerakan-gerakan keagamaan non-tradisional dan informal merupakan bentuk degradasi dan korupsi atas ortodoksi. Sebaliknya, menurutnya justeru gerakan-gerakan itu merupakan cikal bakal utama (vital sources) terhadap perkembangan diskursus ortodoksi baru (Martin \& Barzegar, 2010:180).

Sementara Calder mengajukan lima kriteria untuk mendefinisikan sebuah ortodoksi Islam; kitab suci (scripture), komunitas (community), nalar (reason), pengetahuan mistik-spiritual (gnosis), dan karisma (kharisma) (Calder, 2000:71). Melalui lima kriteria ini, Calder kemudian menjelaskan bahwa, dalam konteks Islam, ortodoksi yang berbasis nalar direpresentasikan oleh para filsuf dan kelompok Mu'tazilah, ortodoksi yang berbasis gnosis direpresentasikan oleh para sufi, dan ortodoksi yang berbasis karisma para imam direpresentasikan oleh Syi'ah Itsna-'Asy'ariyyah dan Isma'iliyyah. Sementara Sunni merupakan representasi dari ortodoksi yang berbasis al-Qur'an (scripture) dan melalui apa yang terjadi dalam komunitas (community), sebuah komunitas yang berproses tanpa henti (the on going community).

Dengan meminjam dan memodifikasi beberapa teori yang dikemukakan di atas, maka dalam penelitian ini dinyatakan bahwa ortodoksi tafsir Sunni dibangun di atas tiga hal. Pertama, orientasi tekstual yang merupakan peminjaman atas teori scripture Calder. Orientasi tekstual ini dimaksudkan bahwa tafsir harus selalu setia dan tidak bertentangan dengan teks, yakni al-Qur'an dan hadith. Dan karena kedua teks tersebut disampaikan melalui bahasa Arab, maka orientasi tekstual juga meliputi pada persoalan-persoalan linguistik. Kedua, pengakuan terhadap otoritas generasi terdahulu. Poin ini merupakan kolaborasi atas teori ummah sebagai level tertinggi dari identitas keagamaan Islam dan yang menjadi pusat penyeragaman konsep teologis dalam sejarah jaringan-jaringan umat Islam (networks in Muslim Society) (Martin \& Barzegar, 2010:194-196) yang diajukan oleh Martin dan community oleh Calder. Poin kedua ini dimaksudkan bahwa setiap upaya penafsiran al-Qur'an pada masa tertentu harus mengkaji dan mempertimbangkan apa yang telah diwariskan oleh generasi sebelumnya, terutama generasi sahabat dan tabi’in yang dipandang lebih otoritatif dibanding generasi-generasi susudahnya. Ketiga, identifikasi teologis kelompok Sunni. Hal ini dimaksudkan bahwa sebuah tafsir juga harus sesuai dan tidak bertentangan dengan batas-batas doktrin yang memisahkan antara Sunni dan kelompok-kelompok di luarnya. 
Demikianlah tiga prinsip yang menjadi struktur dasar ortodoksi tafsir Sunni yang hendak diajukan dalam tulisan ini. Penelitian ini juga meyakini bahwa struktur-struktur dasar semacam ini bersifat relatif permanen. Dengan kata lain, sekalipun terjadi pergeseran-pergeseran di dalamnya namun ia tetap saja tidak menyentuh struktur dasar tersebut. Bahkan sekalipun mampu, ia pun tidak berlangsung secara permanen. Selain itu, pemetaan struktur semacam ini dilakukan, tentu saja, untuk menjadi alat bantu dalam memahami kenapa pergeseran-pergeseran tertentu diterima sementara pergeseran-pergeseran lainnya ditolak untuk menjadi bagian dari ortodoksi tafsir Sunni. Tiga prinsip itu akan diurai pada bagian berikut ini.

\section{Tekstualisme dan Persoalan Linguistik}

Perhatian pada persoalan bahasa dalam proses menafsirkan al-Qur'an merupakan fakta yang sulit dipungkiri. Hal ini terlihat dari intensi yang sangat kuat terhadap persoalan bahasa dalam karyakarya awal tentang kaidah penafsiran al-Qur'an. Atau jika hendak dirumuskan secara berbeda sebagian besar literatur tentang bahasa Arab paling awal menjadikan al-Qur'an sebagai fokus kajiannya. Fenomena semacam ini didasarkan pada asumsi bahwa al-Qur'an lokus bahasa Arab, kitab al'Arabiyyah al-akbar (Shahbah, 1992:9). Selain itu, upaya pengkajian lingusitik terhadap al-Qur'an juga ditengarai sebagai respons terhadap para penganut Manichaeisme yang berpandangan bahwa al-Qu'an bukan suatu kitab yang istimewa (Al-Jabiri, 2009:75-76) dan dengannya turut mendorong elaborasi konsep i'jaz al-Qur'an (Ma'rifah, 1411:31).

Kelompok yang meyakini bahwa i’jaz al-Qur'an berlaku secara umum, baik Arab maupun nonArab, berpandangan bahwa mukjizat al-Qur'an terletak terutama pada maknanya dan bukan pada lafaznya (Al-Jabiri, 2009:76). Sebaliknya, para ulama Sunni ortodoks meyakini bahwa mukjizat alQur'an terletak pada lafaz dan maknanya sekaligus yang keduanya sama-sama bagian internal dari teks itu sendiri (Al-Suyuti, 2002:231). Karena itu, tidak ada satu pun bahasa asing (non-Arab) yang mampu mengekspresikan i'jaz al-Qur'an itu seperti yang bisa dilakukan oleh bahasa Arab. Implikasi dari pandangan ini, maka upaya penerjemahan al-Qur'an menjadi sesuatu yang tidak mungkin dan terlarang. Polemik tentang penerjemahan al-Qur'an bahkan terjadi sampai awal abad ke-20 (Federspiel, 1996:34). Namun belakangan penerjemahan al-Qur'an mulai diterima secara luas dengan asumsi bahwa terjemahan itu merupakan bagian dari tafsir dan tidak boleh menggantikan teks al-Qur'an (AlDzahabi, 2000:23-24).

Selain hal di atas, banyaknya tema-tema dalam literatur kaidah-kaidah tafsir dan 'ulum alQur'an yang fokus pada persoalan bahasa juga bisa dianggap sebagai upaya untuk menetapkan batasan agar al-Qur'an tidak ditafsirkan secara menyimpang dari kaidah-kaidah bahasa Arab (Ichwan, 2002).

Perhatian kepada persoalan-persoalan linguistik ini bermuara pada upaya penetapan relasi antara teks dan maknanya. Dimana relasi tersebut dipahami sebagai relasi yang bersifat tekstualis; pemaknaan apapun terhadap al-Qur'an tidak boleh bertentangan dengan teks (al-Qur'an dan hadith) (Bosworth : 9). Akan tetapi, orientasi tekstual dalam tafsir itu tidak sama dengan literalisme yang kaku dan rigid. Ortodoksi Sunni menolak penafsiran yang dilakukan dengan terlampau literal sebagaimana yang dilakukan oleh kelompok Zahiriyyah (Al-Qarda, 2007:45-50). Dengan pengertian bahwa dalam ortodoksi tafsir Sunni ada pengakuan terhadap dua konteks. Pertama pengakuan terhadap konteks linguistik yang tidak melampaui teks seperti siyaq al-kalam dan munasabah. Kedua, pengakuan terhadap konteks historis yang berlandaskan pada teks, seperti asbab al-nuzul. Sedangkan 
kontekstualisasi yang melampaui teks cenderung tidak ditolak kecuali ada teks lain yang mendukungnya, seperti konsep naskh.

\section{Pengakuan terhadap Otoritas Generasi Terdahulu}

Sebagaiamana jamak diketahui bahwa sumber pengetahuan dalam tafsir umumnya diklasifikasikan menjadi tiga; riwayat, rasio, dan intuisi. Yang pertama melahirkan tafsir bi al-ma'thur, yang kedua melahirkan tafsir bi al-ra'y, dan yang ketiga melahirkan tafsir bi al-isyari.

Sering kita jumpai dalam literatur-literatur tafsir tentang kecenderungan bahwa tafsir bi alma'thsur lebih tinggi posisinya dibanding tafsir bi al-ra'y. Dalam konteks ini, Ignaz Goldziher melakukan investigasi melalui fenomena-fenomena penafsiran al-Qur'an pada masa-masanya yang paling awal. Menurutnya, hingga awal abad kedua Hijriah, upaya menafsirkan al-Qur'an masih dipandang sebagai sesuatu yang "meragukan" dan dilakukan dengan enggan (Golziher, 1955:73). Ada banyak sekali riwayat yang menunjukkan bahwa para ulama di masa-masa tersebut memandang aktivitas interpretasi al-Qur'an dengan rasa tidak suka. Tetapi, tulis Goldziher,

“...penolakan yang keras ini ditujukan kepada tafsir dalam pengertiannya yang khusus: bahwa al-Qur'an tidak boleh ditafsirkan berdasarkan ra'y, yakni pemikiran individu, serta berdasarkan hawa (kecenderungan personal). Cara yang benar dalam menafsirkan al-Qur'an adalah menginterpretasikannya dengan 'ilm...[yaitu] ajaran-ajaran yang bersambung kepada satu-satunya sumber pengetahuan yang diakui, yakni yang bersambung melalui riwayat kepada Rasulullah saw. atau kepada para sahabat...." (Golziher, 1955:80).

Pada perkembangan selanjutnya, umumnya yang dikategorikan sebagai tafsir bi al-ma'tsur ada tiga; penafsiran ayat al-Qur'an dengan ayat al-Qur'an yang lain, penafsiran al-Qur'an dengan hadithhadith Rasulullah saw., serta penafsiran al-Qur'an dengan riwayat para sahabat, plus satu kategori yang sering diperdebatkan, yaitu penafsiran al-Qur'an dengan pendapat para tabi in. (Al-Tayyar, 2010:20). Belakangan klasifikasi semacam ini mulai dipersoalkan. Misalnya tentang penafsiran al-Qur'an dengan al-Qur'an yang oleh sebagian kalangan dianggap tidak layak untuk dikategorikan sebagai tafsir bi alma'thur. Alasannya, menurut kalangan ini, upaya menjadikan sebuah ayat sebagai penafsiran bagi ayat yang lain merupakan aktivitas yang tidak ada hubungannya dengan atsar yang bisa dinisbatkan kepada generasi-generasi penafsir terdahulu, kecuali jika ia merupakan bagian dari kategori-kategori yang lain (tafsir Nabi, sahabat, atau tabi in) (Al-Tayyar : 21).

Selain itu, klasifikasi tafsir ke dalam tafsir bi al-ma'thur dan tafsir bi al-ra'y belakangan menuai kritik. Sebagian menganggap bahwa dualisme di antara keduanya dibangun di atas kriteria-kriteria yang tidak jelas. Tafsir bi al-ma'thur tidak bisa serta merta dilawankan secara biner dengan tafsir bi al-ra'y karena dalam penafsiran-penafsiran yang dikategorikan sebagai tafsir bi al-ma'thur sekalipun di dalamnya tetap saja terdapat aktivitas rasional. Implikasi dari kritik-kritik semacam ini bisa diamati dalam dua hal. Pertama, pembagian karya-karya tafsir ke dalam dua kategori tafsir bi al-ma'thur dan tafsir bi al-ra'y itu kemudian dianggap tidak lagi relevan. Karena itu, tidak ada satu pun karya tafsir yang sepenuhnya bisa disebut sebagai ma'thsur dan steril dari pilihan-pilihan rasional penulisnya. Bahkan apa yang dilakukan al-Tabari untuk mencantumkan dan memprioritaskan (tarjih) riwayatriwayat tertentu dalam karya tafsirnya secara jelas menunjukkan adanya aktivitas rasional dirinya dalam penulisan karyanya itu (Al-Tayyar : 22-23). Kedua, karena tafsir bi al-ma'thur, terutama yang berasal dari sahabat dan tabi'in, juga mengandung aktivitas rasional, maka, dalam hal-hal yang bersifat 
ijtihadiyyah itu, posisinya menjadi sejajar dengan tafsir bi al-ra'y-keduanya sama-sama berpotensi untuk diterima dan ditolak berdasarkan kriteria yang sama (Al-Tayyar : 22).

Kendati demikian, uraian di atas tidak bertentangan dengan asumsi yang dianut dan dikembangkan dalam penelitian ini; bahwa ortodoksi tafsir Sunni dibangun di atas otoritas generasigenerasi pertama, khususnya para sahabat dan tabi'in. Pada umumnya, tafsir yang berasal dari sahabat dan tabi’in ini diklasifikasikan menjadi dua kategori, yakni tafsir yang di dalamnya tidak mengandung ijtihad (seperti tafsir tentang asbab al-nuzul, tafsir tentang hal-hal gaib, dan lain sebagainya) dan tafsir yang berupa ijtihad. Kategori pertama harus diterima selama tidak ada cacat dalam proses periwayatannya. Sedangkan kategori kedua,

“...termasuk dalam kategori al-ra’y al-mahmud karena mereka tidak pernah berkata tentang alQur'an tanpa pengetahuan (bi gayr 'ilm). Mereka juga tidak terpengaruh oleh fanatisme mazhab (hawa madzhabi) yang bisa membuat mereka menyelewengkan makna-makna ayat untuk mendukung apa yang mereka yakini. Maka ketika mereka bebas dari dua hal yang merupakan penyebab terbesar dari munculnya deviasi dalam tafsir, dan mereka juga menafsirkan al-Qur'an berdasarkan pengetahuan, maka pendapat mereka dalam tafsir menjadi terpuji. Pendapat yang da'if dalam tafsir-tafsir mereka bukan merupakan al-ra'y al-madzmum. Sementara pendapat-pendapat yang gharib dari sebagian di antara mereka...juga merupakan sesuatu yang jarang terjadi, bahkan hampir tidak bisa disebutkan.” (Al-Tayyar : 29-30).

Dengan otoritas semacam itu, tafsir generasi-generasi pertama selalu menjadi kerangka rujukan bagi tafsir generasi-generasi berikutnya. Bahkan tafsir bi al-ra'y al-mahmud yang berasal dari generasigenerasi belakangan dibatasi hanya pada dua hal: pertama, tarjih atas tafsir-tafsir generasi pertama, dan kedua, tafsir baru yang tidak bertentangan dengan tafsir generasi pertama (Al-Tayyar : 30-31). Kegiatan penafsiran al-Qur'an memang harus terus dilakukan untuk menjawab tuntutan zaman yang senantiasa berubah, namun,

“...diperlukan batasan-batasan tertentu dalam hal ini, yaitu...bahwa makna [yang ditarik dari al-Qur'an] harus sahih dan sesuai dengan [kaidah-kaidah] bahasa serta tidak bertentangan dengan (yakni tidak membatalkan) pendapat generasi terdahulu (al-salaf). Jika syarat-syarat ini terpenuhi, maka...tafsir baru (al-tafsir al-jadid) dapat dianggap sahih dan dikategorikan sebagai tafsir bi al-ra'y al-mahmud yang didasarkan kepada ilmu." (Al-Tayyar : 30-31).

\section{Identifikasi Teologis}

Sebagaimana diungkapkan pada bagian sebelumnya bahwa indentifikasi teologis ini dimaksudkan bahwa sebuah tafsir harus sesuai dan tidak boleh bertentangan dengan apa yang telah menjadi doktrin teologis dalam dunia Sunni. Pada bagian ini, penulis akan mengeksplorasi dua persoalan penting dan umum diketahui sebagai bukti betapa doktrin-doktrin (teologis) dalam dunia Sunni juga sangat menentukan dalam proses penilaian sebuah karya tafsir al-Qur'an. Pertama, persoalan teologis menyangkut status al-Qur'an; apakah ia makhluq (diciptakan) atau tidak? Perdebatan ini dianggap bersifat teologis karena ia berangkat dari pemerian tentang sifat-sifat Allah serta pernah menjadi kriteria paling penting bagi identifikasi Sunni sebagai sebuah kelompok teologis.

Para ulama Sunni menganut pandangan bahwa al-Qur'an adalah kalamullah yang tidak diciptakan (gayr makhluq) dan tidak bermula (qadim). Pandangan ini berujung pada anggapan bahwa al-Qur'an bersifat ahistoris, berada di luar sejarah—ia tidak bermula dan tidak pula berakhir. Ortodoksi 
Sunni selalu menolak pendapat-pendapat yang menganggap teks al-Qur'an terbentuk melalui proses historis. Sebaliknya, bagi mereka, al-Qur'an telah ada sejak zaman azali, tidak bergantung kepada sesuatu apa pun, dan akan terus abadi (Welch).

Kalangan yang menganut pandangan bahwa teks al-Qur'an mengandung historisitas sering kali menjadikan fakta bahwa al-Qur'an diturunkan secara berangsur-angsur (munajjaman) kepada Rasulullah saw. dan adanya konsep naskh dan sabab al-nuzul sebagai argumen untuk mengafirmasikan historisitas al-Qur'an (Rahman, 2001:145). Namun, bagi ortodoksi tafsir Sunni, argumen-argumen tersebut tidak bisa diterima. Bagi mereka, al-Qur'an memang diturunkan secara berangsur-angsur, tetapi ia telah ada sejak dahulu kala di al-lawh al-mahfuz. Sabab al-nuzul tidak dimaknai sebagai sebab turunnya ayat dalam pengertiannya yang kausalistis_ayat tersebut telah ada sejak zaman azali meski ia baru diturunkan bersamaan dengan peristiwa yang menjadi sabab al-nuzul-nya. Begitu pula dengan konsep naskh, ia tidak boleh dijadikan argumen untuk menyatakan bahwa al-Qur'an tunduk kepada perubahan kondisi sosial. Naskh sepenuhnya merupakan hak perogratif Tuhan dan tidak terjadi di luar pengetahuan-Nya yang bersifat kekal serta serba-meliputi (Al-Hafnawi : 238-342).

Meskipun persoalan apakah al-Qur'an itu makhluq atau tidak sudah tidak sepeting pada masamasa sebelumnya, namun tidak bisa dipungkiri bahwa penyangkalan terhadap aspek historisitas alQur'an tetap menjadi bagian yang sangat signifikan dalam ortodoksi Sunni. Oleh karena itu, adalah sesuatu yang bisa dipahami mengapa konsep tentang al-Qur'an sebagai produk kultural (muntaj thaqafi) selain sebagai produsen kultural (muntij thaqafi) yang digagas oleh Nasr Hamid Abu Zayd (Abu Zayd, 2014:24), misalnya, menuai perdebatan dan penentangan yang keras dari para ulama.

Lagi-lagi, bagi mayoritas ulama Sunni, status al-Qur'an sebagai kalamullah yang tidak diciptakan dan tidak bermula itu membuatnya tidak bisa ditafsirkan kecuali dengan metode "khusus" yang sesuai dengan karakter al-Qur'an sendiri (Rahman : 32). Al-Qur'an berbeda dengan teks-teks biasa yang bisa didekati melalui metode-metode sekuler, seperti hermeneutika, semiotika, analisis literer, dan lain sebagainya. Kesalahan terbesar para pengusung gagasan penggunaan metode-metode sekuler tersebut di mata ortodoksi adalah bahwa mereka menempatkan al-Qur'an pada posisi yang sejajar dengan teks-teks lainnya.

Selain dalam persoalan khalq al-Qur'an, identifikasi Sunni sebagai sebuah kelompok teologis juga terlihat dalam kritik-kritik yang diajukan para ulama Sunni terhadap tafsir-tafsir yang dilakukan oleh lawan-lawan teologis mereka. Salah satu ilustrasi yang bagus adalah tafsir al-Kashshaf, karya alZamakhshari. Meski diakui sebagai salah satu karya tafsir otoritatif dalam menjelaskan aspek-aspek linguistik al-Qur'an, tetap saja al-Kashshaf sering menuai kritik lantaran ia mengandung pandanganpandangan kelompok Muktazilah (Taymiyah : 76).

\section{Generalisasi, Investigasi, dan Pengujian Teori}

Setelah menguraikan tiga prisip yang membentuk struktur dasar ortodoksi tafsir Sunni Pada bagian terdahulu, maka pada bagian ini akan diuraikan tentang investigasi dan pengujian terhadapnya. Sebelum itu, harus segera dinyatakan bahwa sebuah upaya penafsiran al-Qur'an dapat dinyatakan menyimpang dari ortodoksi apabila ia bertentangan dengan satu, dua, atau seluruh prinsip-prinsip tersebut. Adapun pengujian itu akan dilakukan melalui buku al-Ittijahat al-Munharifah fi Tafsir alQur'an al-Karim: Dawafi'uha wa Daf'uha, karya Muhammad Husayn al-Dzahabi. Karya ini dipilih 
karena ia, disadari atau tidak, telah menarik garis pembatas antara ortodoksi dan deviasi dalam tafsir. Melalui pengujian ini, kita bisa mengetahui di mana batas-batas terluar dari ortodoksi sekaligus menilai apakah penyimpangan-penyimpangan itu telah cukup terliput dalam pemetaan yang telah dilakukan pada bagian sebelumnya.

Secara umum, al-Dzahabi mengklasifikasikan tafsir menjadi dua; tafsir bi al-ma'thur dan tafsir bi al-ra'y. Menurutnya, sebagian besar penyimpangan (inhiraf) dalam tafsir bi al-ra'y terjadi dalam dua hal berikut. Pertama, penafsir meyakini sesuatu lalu membawa lafaz al-Qur'an untuk mendukung keyakinannya itu. Dengan kata lain, penyimpangan ini terjadi akibat perhatian yang terlampau besar kepada makna dengan mengabaikan lafaz. Kedua, penafsir melakukan interpretasi terhadap al-Qur'an dengan hanya memperhatikan lafaznya dan mengabaikan konteksnya (Al-Dzahabi, 1986 : 18-20).

Demi tujuan uraian atas menjadi sistematis, maka dalam penelitian ini akan dilakukan pengujian terhadap salah satu karya Muhammad Husein al-Dzahabi, al-Ittijahat al-Munharifah fi Tafsir al-Qur'an: Dawafi'uha wa Dafuha. Namun aplikasinya tidak mengikuti urutan dalam buku al-Dzahabi tetapi ia akan diurai secara sporadis dengan mengikuti urutan struktur ortodoksi yang dijelaskan pada bagian terdahulu.

a. Deviasi tafsir dan prinsip tekstualisme dan persoalan linguistik

Dalam konteks penyimpangan terhadap prinsip pertama ini, al-Dzahabi menyebut al-Sulami (w. 412) telah melakukan penyimpangan ketika menafsirkan "uqtulu anfusakum" dalam surah al-Nisa' [4]: 66 dengan makna "memerangi hawa nafsu" (Al-Sulami, 2001:154) dan "akhriju min diyarikum" dengan "mengeluarkan kecintaan terhadap dunia dalam hati". Dengan penafsiran semacam itu, alDzahabi menganggapnya sebagai makna "yang tidak dikehendaki” (ghayr muradah) oleh al-Qur'an (AlDzahabi : 20-21).

Akan tetapi, sebagaimana dijelaskan pada bagian sebelumnya, orientasi tekstual itu berbeda dengan literalisme yang kaku dan rigid. Karena itu, penafsiran kata "mubsirah" dalam surah al-Isra” [17]: 59 dengan makna "[unta yang] bisa melihat", meski sah secara literal, dianggap salah oleh alDzahabi lantaran ia tidak memperhatikan konteks ayat (siyaq al-kalam)—konteks yang sepenuhnya digali dari relasi antar bagian teks itu sendiri. Kata "mubsirah" dalam ayat tersebut seharusnya dimaknai sebagai "bukti yang jelas tentang kebenaran kenabian” (Al-Dzahabi : 23-24).

Al-Dzahabi juga menyebut para penganut mazhab nahw yang fanatik sebagai kelompok yang menyimpang dari orientasi teks. Dimana mereka seringkali mengorbankan riwayat yang sahih demi teori linguistik yang mereka yakini. Al-Zamakhsyari (w. 538 H.) dan Ibn 'Atiyyah (w. 546 H.), dalam tafsir mereka berdua terhadap surah al-An'am [6]: 137, menolak sebuah qira'ah yang mutawatir dengan anggapan bahwa qira'ah tersebut bertentangan dengan mazhab nahw yang mereka anut ('Atiyyah, 1993:349-350). Terhadap kecenderungan tersebut, al-Dzahabi menyatakan, “...Tidaklah layak bagi alZamakhsyari maupun bagi orang lain untuk menjadikan mazhab nahw yang dia anut sebagai penilai kitabullah. [Sebaliknya], kitabullah adalah sumber yang harus dirujuk dan dijadikan argumen untuk menghakimi setiap pertentangan yang terjadi di antara para ahli nahw”. (Al-Dzahabi : 23-24).

Kasus lain yang disebut oleh al-Dzahabi sebagai penyimpangan terhadap prinsip pertama ini adalah mereka-mereka yang tidak memiliki pengetahuan mendalam tentang kaidah-kaidah bahasa Arab. Misalnya penafsiran yang dilakukan oleh sebagian kelompok Mu'tazilah terhadap ayat "wasi'a kursiyyuhu al-samawat wa al-ardh" dalam surah al-Baqarah [2]: 255 dengan "luasnya ilmuNya" (wasi'a 
'ilmuhu) dengan merujuk pada sebuah syair "dan [ilmu] makhluk tidak seluas ilmu Allah” (wala yukarsiu 'ilm Allah makhluq). Tentang penafsiran semacam ini, Ibn Qutaibah membantahnya dengan ungkapan "kata kursiyyun dalam ayat tersebut, secara bahasa, merupakan kata yang bina'nya ghayr mahmuz. Sementara yukarsiu dalam syair itu adalah mahmuz". (Al-Dzahabi : 44).

\section{Deviasi Tafsir dan Prinsip Pengakuan Terhadap Otoritas Generasi Terdahulu}

Secara umum, bantahan al-Dzahabi terhadap penafsiran yang dilakukan oleh kelompok Mu'tazilah dan Syi'ah memang, terutama, terletak pada pertentangan mereka pada prinsip pertama dan ketiga, namun al-Dzahabi juga merujuk kepada otoritas para ulama hadith dan jumhur al-mufassirin dalam bantahannya. Itu tampak, misalnya, dalam bantahannya terhadap argumen kelompok Mu'tazilah ketika mereka menafsirkan surah al-Qiyamah [75]: 22-23 untuk menolak pandangan kelompok Sunni tentang kemungkinan melihat Allah di akhirat nanti (Al-Zamakhsyari, 649-650). Dan ketika Ibrahim ibn Furat al-Kufi, salah seorang ulama Syi'ah Itsna-'Asyariyah, menyatakan bahwa yang dimaksud dengan "al-naba' al-'azim” dalam surah al-Naba' [78]: 2 adalah 'Ali ibn Abi Talib, al-Dzahabi membantahnya dengan menyatakan bahwa argumen tersebut bertentangan dengan siyaq al-surah (AlDzahabi: 57) Akan tetapi al-Dzahabi juga merujuk kepada otoritas para ulama hadits dan jumhur almufassirin dalam bantahannya terhadap tafsir kelompok Syiah. Seluruh riwayat yang menyatakan status kewalian 'Ali, berdasarkan ketetapan para ulama hadits, dianggap tidak memiliki dasar serta sekedar merupakan upaya kelompok Syi'ah untuk menyokong pendirian teologis mereka (AlZamakhsyari, 1998 : 537).

Pengakuan al-Dzahabi terhadap otoritas generasi terdahulu juga terlihat dalam sanggahannya terhadap pendapat al-Mawla 'Abd al-Latif al-Kazarani tentang tafsir ayat "kaf-ha'-ya'-ayn-sad” (surah Maryam [19]: 1), al-Dzahabi menyatakan bahwa hal itu bertentangan dengan kesepakatan mayoritas ulama tafsir tentang makna al-huruf al-muqatta'ah di awal sebagian surah dalam al-Qur'an (Al-Dzahabi :61-62).

\section{Deviasi Tafsir dan Prinsip Identifikasi Teologis}

Penafsiran kata "dzara'na" dalam surah al-A'raf [7]: 179 dengan makna "alqayna", misalnya, selain menunjukkan bahwa sang penafsir tidak mengetahui kaidah-kaidah bahasa Arab, menurut alDzahabi juga disebabkan oleh keinginan untuk membenarkan sebuah pandangan teologis bahwa "Allah tidak menciptakan petunjuk dan kesesatan serta tidak menentukan sebelumnya siapa yang masuk neraka dan siapa pula yang masuk surga” (Al-Dzahabi : 45). Begitu juga kata "imam” dalam surah alIsra' [17]: 71 yang dimaknai sebagai bentuk plural dari “umm”. Al-Dzahabi, dengan mengutip alZamakhsyari, menyatakan bahwa pemaknaan tersebut tidak dibenarkan secara linguistik dan mengandung tendensi untuk memuliakan Nabi Isa serta Hasan dan Husayn, dua putera 'Ali ibn Abi Talib (Al-Dzahabi : 46).

Argumen-argumen yang sama juga diajukan al-Dzahabi untuk membantah penyimpangan tafsir yang dilakukan oleh kelompok Khawarij dan para sufi. Penafsiran kaum Khawarij yang menggunakan surah Ali 'Imran [3]: 97, al-Ma'idah [5]: 44, dan al-Taghabun [64]: 292 untuk mendukung keyakinan bahwa status pelaku dosa besar adalah kafir, menurut al-Dzahabi, lahir sebagai akibat dari pengabaian konteks ayat, fanatisme kelompok, dan ketidaktahuan akan hadits-hadits Rasulullah saw. tentang status para pelaku dosa besar (Al-Dzahabi : 64-65). 
Salah satu proponen kaum sufi yang banyak ditentang pendapatnya oleh al-Dzahabi adalah Ibn 'Arabi (w. 638 H.). Dalam tafsirnya terhadap ayat “wa ilahukum ilah wahid” (al-Baqarah [2]: 163), Ibn 'Arabi menyatakan bahwa Tuhan kaum muslimin dan Tuhan kaum musyrikin sebetulnya satu. Sementara ketika menafsirkan surah al-Muzzammil [73]: 8, Ibn 'Arabi menyatakan, "Ingatlah Tuhanmu, yakni dirimu sendiri. Artinya, kenali dan ingatlah dirimu. Jangan sampai engkau melupakannya sehingga Allah pun akan melupakanmu. Dan berusahalah untuk mencapai kesempurnaan diri setelah engkau mengetahui hakikatnya....". Tafsir semacam itu ditentang oleh alDzahabi karena ia bertolak dari pandangan wihdah al-wujud serta asumsi-asumsi filosofis yang bertentangan dengan al-Qur'an dan agama Islam (Al-Dzahabi, 2000: 253).

Sementara dalam kasus kesalahan tafsir saintifik (al-tafsir al-ilmi), menurut al-Dzahabi, disebabkan oleh pengabaian karakter dasar teks al-Qur'an yang bukan merupakan "kitab filsafat, kedokteran, atau teknik” (Al-Dzahabi : 90). Sedangkan para penyokong gerakan pembaharuan dalam tafsir cenderung melakukan interpretasi al-Qur'an dengan mengabaikan kaidah-kaidah bahasa, sunnah Rasulullah saw., dan hikmah al-tasyri'. Ketika orang-orang tertentu menolak aplikasi hukum hudud yang ditetapkan oleh al-Qur'an, maka apa yang mereka lakukan itu, menurut al-Dzahabi, bertentangan dengan kaidah bahasa Arab yang menegaskan bahwa perintah al-Qur'an tersebut bersifat mewajibkan (al-amr li al-wujub), bertentangan dengan Sunnah yang menyatakan bahwa Rasulullah saw. sendiri melakukan hukum hudud tersebut, serta bertentangan juga dengan hikmah di balik penetapan hukum syariat (Al-Dzahabi, 93-99).

\section{Penutup}

Demikianlah uraian tentang struktur dasar ortodoksi tafsir Sunni. Meskipun artikel ini tidak memungkiri bahwa ortodoksi, termasuk dalam dunia Sunni, merupakan fakta yang terus berkembang, dinamis, dan tidak dikonstruksi sekali jadi, namun penelitian ini menunjukkan bahwa di atas itu semua, dalam sebuah ortodoksi selalu ada struktur dasar yang relatif bersifat permanen. Adapun struktur dasar ortodoksi tafsir Sunni ada tiga; orientasi tekstual (sebuah tafsir dianggap menyimpang karena ia bertentangan dengan penegasan al-Qur'an sendiri, hadits-hadits Nabi, atau kaidah-kaidah bahasa), pengakuan terhadap otoritas generasi terdahulu (sebuah tafsir dianggap menyimpang karena ia bertentangan dengan tafsir yang ma'tsur dari generasi pertama atau bertentangan dengan pendapat mayoritas ulama), serta identifikasi teologis kelompok Sunni (sebuah tafsir dianggap menyimpang karena ia lahir dari asumsi-asumsi teologis non-Sunni) sebagaimana hal ini telah coba dilakukan pengujian melalui analisa terhadap buku al-Ittijahat al-Munharifah fi Tafsir al-Qur'an: Dawafi'uha wa Daf uha karya Muhammad Husein al-Dzahabi.

Tulisan ini, tentu saja, tidak berpretensi untuk memberikan deskripsi yang tuntas, terperinci, dan menyeluruh. Kajian tentang ortodoksi tafsir Sunni bisa diperluas dengan, misalnya, melalui analisa atau lensa yang lain, seperti genre tafsir. Sebagaimana hal itu pernah dilakukan oleh Norman Calder yang berupaya melacak struktur mendasar dari sebuah ortodoksi tafsir Sunni melalui kajiannya terhadap tafsir al-Thabari sampai Ibn Kathir dengan studi tematik terhadap kisah Nabi Ibrahim.

\section{Daftar Pustaka}

Abu Shahbah, Muhammad, 1992, al-Madkhal li Dirasat al-Qur'an al-Karim, Beirut: Dar al-Jayl. 
Abu Zayd, Nasr Hamid, 1998, Mafhum al-Nass: Dirasah fi 'Ulum al-Qur'an (Beirut: al-Markaz alTsaqafi al-'Arabi.

Arkoen, Mohammed, 1994, Rethinking Islam: Common Questions, Uncommon Answers, terj. Robert D. Lee, Boulder, Corolado: Westview Press.

C.E. Bosworth, dkk. [ed.], The Encyclopaedia of Islam, WebCD Edition

Calder, Norman, 1993, Tafsir from Tabari to Ibn Kathir: Problem in The Discription of a Genre, Illustrated with Reference to The Story of Abraham' dalam Approaches to The Qur'an, ed. G. R. Hawting and Abdul Kader A. Shareef, London and New York.

Calder, Norman, 2000, “The Limits of Islamic Orthodoxy”, dalam Farhad Daftary [ed.], Intellectual Traditions in Islam, London: I.B. Tauris.

Donough, Sheilla Mc. , 1993, "Orthodoxy and Heterodoxy", dalam Mircea Eliade (ed), The Encyclopedia of Relegion, New York: Simon \& Schuster Macmillan.

Dzahabi, Muhammad Husayn, 2000, al-Tafsir wa al-Mufassirun, Kairo: Maktabah Wahbiyyah.

Dzahabi, Muhammad Husayn, 1986, al-Ittijahat al-Munharifah fi Tafsir al-Qur'an: Dawafíuha wa Daf uha, ttp, Maktabah Wahbiyyah.

Federspiel, Howard, 1996, Kajian al-Qur'an di Indonesa: Dari Mahmud Yunus hingga Quraish Shihab, terj. Tajul Arifin, Bandung: Mizan, cet. 2.

Golziher, Ignaz, 1955, Madzahib al-Tafsir al-Islami, terj. Abdul Halim al-Najjar, Kairo: Matba'at alSunnah al-Muhammadiyyah.

Gunther, Ursula, 2004, "Mohammed Arkoen: Towards a Radical Rethinking of Islamic Thought", dalam Suha Taji-Farouki [ed], Modern Muslim Intellectuals and The Qur'an, Oxford: Oxford University Press.

Hafnawi, Muhammad Ibrahim, Dirasat fi al-Qur’an al-Karim, Kairo: Dar al-Hadits.

Ibn 'Atiyyah, al-Muharrar al-Wajiz fi Tafsir al-Kitab al-'Aziz, Beirut: Dar al-Kutub al-'Ilmiyyah, 1993

Ichwan, Nor, 2002, Memahami Bahasa al-Qur'an: Refleksi atas Persoalan Linguistik, Yogyakarta: Pustaka Pelajar.

Jabiri, 2000, Bunyah al-'Aql al-'Arabi, Dirasah Tahliliyyah Naqdiyyah li Nuzum al-Ma'rifah fi alThaqafah al-'Arabiyyah, Beirut: Dar al-Bayda'.

Khalidi, Salah 'Abd al-Fattah, 2008 ,Ta'rif al-Darisin bi Manahij al-Mufassirin, Damaskus: Dar alQalam.

Ma'rifah, Muhammad Hadi, $1411 \mathrm{H}$, al-Tamhid fi 'Ulum al-Qur'an, Qum: Muassasah al-Nasyr alIslami.

Mahna, Ahmad Ibrahim, Dirasah Hawla Tarjamah al-Qur'an al-Karim, ttp.: Matbu'at al-Sya'b.

Martin, Richard C. \& Abbas Barzegar, 2010, "Formations of Orthodoxy: Authority, Power, and Networks in Muslim Societies", dalam Carl W. Ernst ed. Rethinking Islamic Studies: From Orientalism to Cosmopolitan, Columbia: University of South Carolina Press. 
Saeed, Abdullah, 2006, Interpreting the Qur'an: Towards a Comtemporary Approach, (USA and Canada: Routledge.

Saleh, Fauzan, 2004, Teologi Pembaruan: Pergeseran Wacana Islam Sunni di Indonesia Abad XX, Jakarta: Serambi.

Suyuti, Jalaluddin, 2002, al-Itqan fi 'Ulum al-Qur'an, Beirut: Dar al-Kutub al-'ilmiyyah.

Tayyar, Musa'id, 2010, Mafhum al-Tafsir wa al-Ta'wil wa al-Istinbat wa al-Tadabbur wa al-Mufassir, Riyadh: Dar Ibn Jauzi.

Tietge, David, 2004, "Complexity Theory and Evolutionary Discourse", dalam JAC, Vol. XXIV, No. 4, Special Issue: Complexity Theory.

Utsaimin, Salih, Syarh Muqaddimah Ushul al-Tafsir, Riyadh: Dar al-Watan.

Watt, Montgomery, 1973, The Formative Period of Islamic Thought, Edinburg: Edinburgh University Press.

Zamakhsyari, Abu Qasim Mahmud, 1998, al-Kasshaf 'an Haqaiq Ghawamid al-Tanzil wa 'uyun alAqawil fi Wujuh al-Ta'wil, Riyadh: Maktabah al-'Ubaikan. 